\title{
Ornaments as an Element to Forming Interiority in Utama Mandala Pura Agung Wiralokanatha
}

\author{
Mrs.Febry Maharlika \\ Department of Interior Design \\ Universitas Komputer Indonesia \\ Bandung, Indonesia \\ febry.maharlika@email.unikom.ac.id
}

\begin{abstract}
The purpose of this research is to describe the interiority formed by ornaments in the Utama Mandala area of the Pura. The research method used is the descriptive analysis, by presenting data about the philosophical meaning of ornaments, which associated with the tendency of the human body. In this case, the ornaments in Utama Mandala help Hindus interpret space based on the concept of space and time. The upper direction shows the future, the downward direction shows the past, the front shows sacred. The back shows profane, and so on. The placement of ornaments in each building in the utama mandala has been arranged according to the prevailing standard, so that the philosophical meaning of the ornament can be read as a single ornament, or read as a whole. The conclusion obtained in this study is the placement of ornaments in the utama mandala, helping the people to interpret Utama Mandala as a sacred area, where there are many contents of the teachings of Hinduism about the nature of life. With this research, it is known that the role of ornaments in an architecture is not only as a complementary element, but as an element that can form interiority..
\end{abstract}

Keywords — ornament, pura, utama mandala, interiority

\section{INTRODUCTION}

Pura is a place of worship for Hindus in Indonesia where there are sacred buildings with high philosophical meaning. Every building in the pura is always decorated with ornaments. Ornaments are one element that cannot be separated from buildings in the pura. Ornaments found in the pura manifest in the form of god ornaments, plant ornaments, animal ornaments, and the most sacred are ornaments in the form of chairs / thrones. Not only as a complement, the ornaments in the utama mandala are also embodiments of the teachings of Hinduism which can be read by its location.

Ornamen-ornamen yang ada di pura memiliki makna untuk umat Hindu. Berkaitan dengan hal tersebut, penelitian ini membahas interioritas yang terbentuk oleh ornamen yang ada pada area utama mandala pura. Menurut McCarthy [7] interioritas merupakan intimasi yang memproyeksikan identitas sebagai refleksi pengguna di dalamnya. Berbeda dengan interior, interioritas dapat diartikan sebagai rasa interior yang muncul, meskipun tidak berada di dalam ruang interior [6]. Rasa interioritas telah melampaui pengalaman seseorang di dalam ruangan.

The ornaments in the pura have philosophical meaning for Hindus. In this regard, this study discusses interiority formed by ornaments in the utama mandala pura. According to McCarthy [7] interiority is an intimacy that projects identity as a reflection of the user in it. Unlike the interior, interiority can be interpreted as an interior feeling that arises, even if it is not in the interior space [6]. The sense of interiority has exceeded the experience of someone in the room.

The activities of the people while worshiping, forming a space based on ornaments applied to the building. For example, in the procession of worship, the people 's gestures are centered on the building of padmasana as a place for Sang Hyang Widi Washa / God Almighty. In that event, the people formed a space, where the space was not bounded by a wall.

This research is useful for expressing the role of interior science regarding human experience interpreting space in carrying out worship, especially Hindus who worship at Pura. Pura is a place of worship, not only as an object, but also provides a spatial context for Hindus who worship in it. While the ornaments in it reinforce the concept. Ornaments applied to buildings in the main area of the mandala temporarily create a perception for Hindus who worship in it. This perception arises because of the collaboration of sensory work, the brain, and the instinct of each individual. From these perceptions and interpretations, Hindus who worship at the pura, especially the main area of the mandala, feel spatial memory and then interpret the space so that a spatial context emerges. From this, interiority arises in Hindus, so there is a sense of solemnity when performing worship in the utama mandala.

The research about tracing interiority in interactive learning media related to the process of growth and development of preschoolers where the experience of child space is used as an aspect of forming interiority. Darmawan, Rully in his dissertation discusses the phenomenon of spatial biology in the event of the use of the Nintendo WII game console. The discussion of interiority in this study is about the concept of virtual space that individuals feel when playing games using the Ninterndo WII console. While the research on Balinese ornaments, the author had previously done, namely regarding the spatial relationship between ornaments, which contributed data and understanding in this study. Different from previous research, this study not only discusses about spatial relation, but discusses about the interiority formed from the ornament itself. These studies become references in this study. The purpose of this study is to describe the role of interior science in Hindu worship activities. 


\section{METHOD}

This study uses descriptive analysis method with a qualitative approach. According to Denzin and Lincoln qualitative research is the study of empirical cultural phenomena in the field. Researchers involved themselves in the search for data directly in Pura Agung Wira Loka Natha, Cimahi - West Java for approximately 3 years. This empirical quality is intended to deepen the validity of data, such as the type of ornament that is on the utama mandala, then the behavior of Hindus in worship activities. With this type of descriptive research, the author describes how interiority can be formed by ornaments in the utama mandala pura [4].

From a scientific point of view, this research contains educational values and spiritual values. The value of education obtained is not only obtained from the truth of the data and theory, this research also explains a philosophical values contained in the ornaments in the pura. In addition, the ornaments in the utama mandala pura are full of spiritual symbols, where Hindus as a buffer society are very respectful of the spiritual values taught.

\section{RESULT}

Ornaments in the utama mandala Pura Agung Wira Loka Natha is one of the elements forming interiority in Hindus who worship in it. This is because ornamentation becomes a symbol of every building where the people treat it very differently according to the level of sacredness.

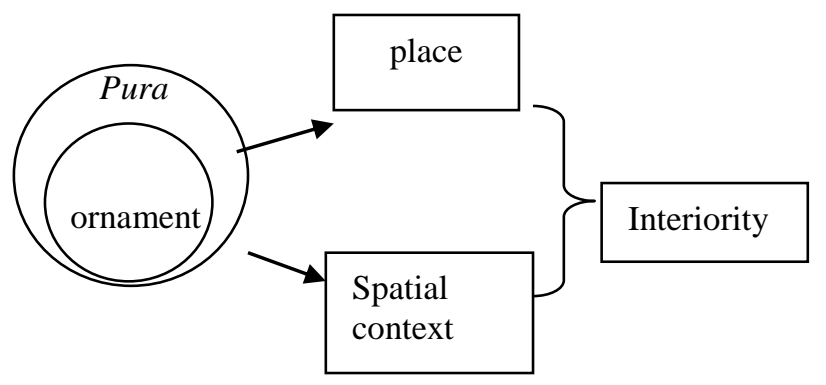

Chart 1. Elements that create interiority in pura Source :Maharlika (2018)

The teachings of Hinduism, not only contained in the holy book, but manifested in a visual form, can be accepted by the human senses in the form of ornaments. The experience of Hindus in religion is integrated with the experience of space in the pura so that the main area of the mandala puras has a spatial context for its people, resulting in interiority.

\section{DISCUSSION}

Pura as a place/ object used for worship activities, has a spiritual value by Hindus as a sacred place. An object that can be felt by the five human senses. By interpreting the pura as a place of spiritual value, Hindus also respect and maintain the pura in accordance with the norms imposed by the existing socio-cultural environment.

This pura is divided into three parts: nista mandala, madya madala, utama mandala. The utama mandala is the deepest (holiest) area of the pura complex (Fig.1), which is the center of Hindu worship activities.

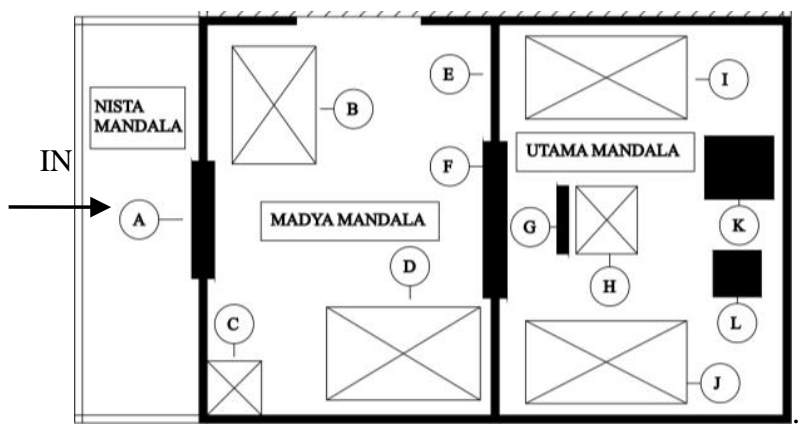

Fig.1 Pura Agung Wira Loka Natha Plan

Source: Maharlika (2014)

Buildings in this area are: kori agung $(\mathrm{F})$, aling-aling $(\mathrm{G})$, bale pawacita $(\mathrm{H})$, bale Piyasan $(\mathrm{J}, \mathrm{I})$, padmasana $(\mathrm{K})$, and panglurah (L). The main buildings in this area are padmasana buildings, Agung kori, Panglurah, and AlingAling. From the main buildings, the most sacred is the padmasana building, because it is the place of the Supreme Lord / Sang Hyang Widi Washa.

The entrance to this area, called kori agung, where after passing through this gate, the people who will pray to Sang Hyang Widi Washa, must focus and not think about things that are worldly. It contains the concept of space and time in the pura area. The people are in the same place (inside the pura), but when it has entered the utama mandala, it is as if in a different space and time. This is related to what Hevjel and Frier (2011) say, that gesture analysis can create a spatial hierarchy in a space. The difference in the level of sacredness in the pura is a spatial hierarchy that is formed because of the human body and mind, in this case Hindus.

In addition, the spatial context in the utama mandala is not spared from posture, the structure of the human body and the relationship between humans. According to Tuan (2007) The concept of space and time for humans can be described as below (Fig. 2). This can be seen from the location of the building, as well as from the configuration of the plant that is applied to all buildings in the utama mandala. For example: reliefs attached to an aling-aling building can be read only if read from the front of the building towards the back of the building. Similarly, the religious teachings contained in the ornaments, are always read from the bottom up 
UPRIGHT HUMAN BODY, SPACE AND TIME

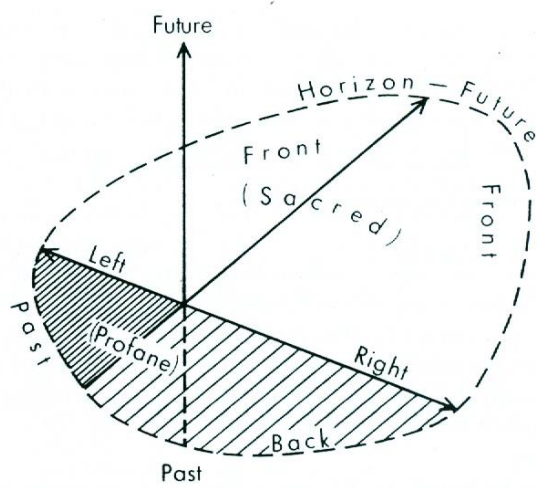

Fig.2 concept of space and time

Source: Tuan (2007)

The ornamental configuration in the Pura Agung Wira Loka Natha area, is a manifestation of the concept of space and time, such as Fig. 3, laying ornaments that are in the kori agung building, can be read from the bottom up, which, if linked, the symbolic meaning of each ornament implies the teachings of Hinduism. According to Maharlika (2014), ornaments applied to each building in the utama mandala of the Pura Agung Wira Loka Natha have spatial relationships that contain Hindu teachings.

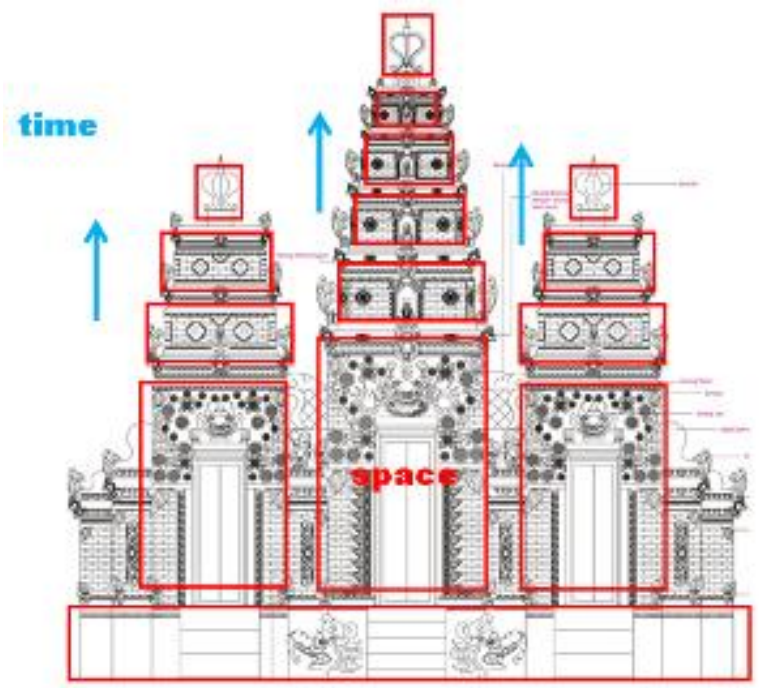

Fig. 3 Concept of space and time in the kori agung building

Source: Maharlika (2014)

In religious ceremonies, Hindus always concentrate the worship ceremony on the front of the padmasana building. The worship activities with moving activities are carried out from left to right, clockwise. As happened in the Siwalatri ceremony, there is a procession of storing holy water / tirta amerta to the top of the padmasana building, namely on the throne ornament. At this ceremony, Tirta Amerta is carried by Pandita and the people surround the utama mandala three times from left to right, as shown in fig. 4.

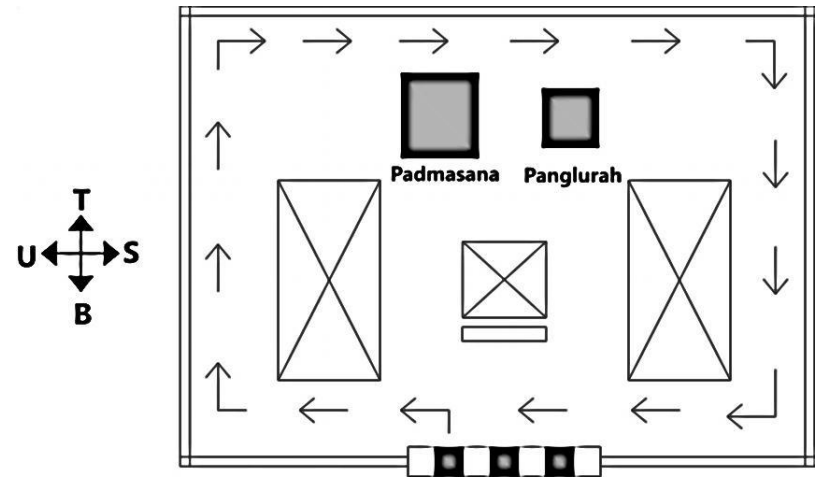

Fig.4 Orientation of the direction of the people when the procession surrounds the utama mandala at the Siwalatri ceremony

Source: Maharlika (2014)

With this direction orientation, the ornaments in utama mandala can be read thoroughly. In previous studies (Maharlika, 2014) found the content of Hindu religious teachings on ornaments in each main building in the utama mandala based on the spatial relationship between ornaments.

\section{A. Ornaments on Padmasana}

Ornaments applied to the padmasana building contain Hindu religious teachings about the unification of Athman (human soul) with Brahman (God Almighty / Sang Hyang Widi Washa).

\section{B. Ornaments on Panglurah}

Ornaments applied to the panglurah building contain teachings of Hinduism, which is a representation of beings in the universe as the creation of God Almighty.

\section{Ornaments on aling-aling}

Ornaments applied to the aling-aling building contain the teachings of Hinduism regarding the nature of man as the creation of God Almighty.

\section{Ornaments on the kori agung}

The ornaments applied to the kori agung building contain teachings about surrendering to the Almighty God, by abandoning worldly things, in order to attain moksa.

The spatial relationship between ornaments can be read into a unified whole by reading it from the bottom to the top. Same as Tuan, expressed about the concept of space and time.

\section{CONCLUSION}

Ornaments found in the utama mandala have philosophical and spiritual meaning. The teachings of Hinduism contained in ornaments can be read in accordance with the tendency of Hindus in particular and humans in general. Ornaments become part of the Hindu ritual worship space in the temple, so that what is meant by each people is a spiritual space. 


\section{ACKNOWLEDGMENT}

I would like to say thank you to unikom for giving this opportunity to do this research. in addition, thanks are also given to the academics in the interior design study program who always provide support during the research.

\section{REFERENCES}

[1] Power.J, "Interior space: representation, occupation, well-being and interiority", [PDF File],(2014), available from www.raco.cat.

[2] Pratitha.Ayu,Paramitha Atmodiwirjo,"Penelusuran Interioritas pada Media Pembelajaran Interaktif Terkait Proses Tumbuh Kembang Anak Hingga Usia Prasekolah (The study of Interiority in Interactive Learning Media Related to the Growing Process of Children to Preschool Age) [PDF File],(2014), available from www.lontar.ui.ac.id

[3] Hendriyana.Husen, "Metodologi Kajian Artefak Budaya Fisik :Fenomena Visual Bidang Seni" (Methodology of Study of Physical Culture Artifacts: Visual Phenomena in the Field of Art), Sunan Ambu STSI press, Bandung,(2009)

[4] Gelebet. I Nyoman, dkk,"Arsitektur Tradisional Daerah Bali"(Traditional Architecture of Bali),Departemen Pendidikan dan Kebudayaan Proyek Inventarisasi dan Dokumentasi Kebudayaan Daerah(Ministry of Education and Culture The Project of Inventory and Documentation of Local Culture),Bali, (1982)

[5] Hvejsel, Marie Frier, "Interiority: - a critical theory of domestic architecture", [PDF File],(2011), available from www.vbn.aau.dk

[6] Maharlika.Febry. "Ornamen pada Bangunan di Utama Mandala Pura Agung Wira Loka Natha Cimahi-Jawa Barat:Hubungan Spasial antar Ornamen yang diterapkan pada bangunan di utama mandala, pura agung wira loka natha, cimahi-jawa barat"( Ornaments on Buildings in the Utama Mandala Pura Agung Wira Loka Natha Cimahi-West Java: Spatial Relations between Ornaments applied to buildings in the utama mandala, Pura agung wira loka natha, cimahi-jawa barat,Tesis (Thesis),Program Magister Seni (Master of Arts Program) ,Sekolah Tinggi Seni Indonesia, Bandung,(2014).

[7] Tuan. Yi-fu, "Space and Place The Perspektive of Experience",University of Minnesota Press, Minneapolis", (2007) 